\title{
Causality of incest: a reply to ten Kate
}

\author{
Michael Krawczak • Jürgen Goebel
}

Received: 3 September 2013 / Accepted: 10 September 2013 / Published online: 20 September 2013

(C) Springer-Verlag Berlin Heidelberg 2013

In a 2010 case report describing the 20 -year-old offspring of father-daughter incest who suffered livelong psychomotor health problems, Schmidtke and Krawczak [1] exemplified the quantification of the causality probability pertinent to such cases. Their study was motivated by the fact that had the incest been causal with probability $>50 \%$, then the patient would have been entitled to compensation under the German Victim Indemnification Act ("Opferentschädigungsgesetz"). Schmidtke and Krawczak [1] argued that the incest was "causative" of the disease at least if the patient was autozygous for one or more mutations that, in the homozygous state, led to her disease. Such "causal autozygosity" is a sufficient although not a necessary condition for causality of the incest, so that the probability of the former represents a lower limit to the latter.

In a Letter to the Editor published in the present issue of IJLM, ten Kate [2] partly negates this line of argument by claiming that, even if the child had inherited only one diseasecausing allele from her father, and if the maternal diseasecausing allele originated from an unrelated person (allozygosity or compound heterozygosity), "the disorder in the child is causally related to the incestuous relation of its parents" as well. We agree with this assertion in so far as, assuming allozygosity or compound heterozygosity, the parental relationship by itself was also causal for the disease. However, this type of causality does not in our view embrace causality of the incest as a criminal act, as in the sense of the German Victim Indemnification Act.

The relevant passage of the act reads as follows: "Wer [...] infolge eines vorsätzlichen, rechtswidrigen tätlichen Angriffs $[\ldots]$ eine gesundheitliche Schädigung erlitten hat, erhält $[\ldots]$

M. Krawczak $(\bowtie)$

Institute of Medical Informatics and Statistics, Christian-Albrechts University at Kiel, Brunswiker Straße 10, 24105 Kiel, Germany

e-mail:krawczak@medinfo.uni-kiel.de

J. Goebel

RAe Goebel und Scheller, Bad Homburg v.d.H., Germany
Versorgung" [3]. The German word "infolge" may be translated as "in consequence of" which, in the context of the act, is held to be tantamount to conditio sine qua non by many German legal experts [4]. The consequence ("disease") should not be without the cause ("incest") - which is certainly not true in the situation in question. However, what is more important is that there appears to be a scholarly consensus that the consequence needs to be specific to the criminal character of the cause [5]. Thus, the idea behind the act is clearly that the state should step in to cover the surplus risk that the patient faced due to the incest, but not to cover any unspecific risk reflecting the possibility of bad luck which, in her case, unfortunately led to a calamity that was concurrent with the incest — but that was nevertheless unrelated to it.

In holding this view, we regard ourselves as being in good company! For example, the Encyclopedia Britannica defines "causation" as "a relation that holds between two temporally simultaneous or successive events when the first event (the cause) brings about the other (the effect)." [6] Undoubtedly, incest as such does not "bring about" allozygosity or compound heterozygosity. On the contrary, both are more likely in outbred matings and are therefore not covered by the public responsibility recognized by the German Victim Indemnification Act.

\section{References}

1. Schmidtke J, Krawczak M (2010) Psychomotor developmental delay and epilepsy in an offspring of father-daughter incest: quantification of the causality probability. Int J Legal Med 124:449-450

2. ten Kate LP (2013) Psychomotor developmental delay and epilepsy in an offspring of father-daughter incest: quantification of the causality probability. Int J Legal Med 124(5):449-450

3. www.gesetze-im-internet.de/bundesrecht/oeg/gesamt.pdf

4. Kunz E, Zellner G, Gehlhausen R, Weiner B (2010) Kommentar zum OEG, 5th edn. Ch Beck, Munich, pp 220-221

5. Knickrehm S (2012) Gesamtes Soziales Entschädigungsrecht. Nomos, Baden-Baden, pp 743-744

6. http://www.britannica.com/EBchecked/topic/100434/causation 